\title{
ZYGMUNT KRASIŃSKI U WÓD
}

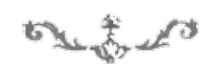

$\left\{\begin{array}{l}\text { IOGRafia Zygmunta KRAsińsKiego po } 1830 \text { roku jest w dużym stopniu } \\ \text { związana z europejską kultura uzdrowiskowa - w różnych aspektach }{ }^{1} \text {. }\end{array}\right.$ Krótsze i dłuższe pobyty „u wód” - jak wtedy mawiano - wiązały się nie tylko z kuracyjną koniecznością, lecz także z charakterystyczną dla epoki modą. Bywanie w sezonie to nie tylko picie wód i kąpiele, ale również towarzyskie obowiązki i przyjemności: spacery, bale, reuniony, wizyty, wycieczki, gry w karty i odwiedzanie kasyna (jak w Baden). W pamiętnikach i listach z epoki romantyzmu odnajdziemy wiele świadectw tego „podwójnego” życia w modnych badach ${ }^{2}$. Także w epistolografii Krasińskiego przewija się owa zdrojowa

1 Najpełniej „biografię uzdrowiskową” Krasińskiego przedstawia - opierając się na obficie wykorzystywanym materiale epistolograficznym - Zbigniew Sudolski (Krasiński, Warszawa 1997). Pojawiają się ostatnio także ujęcia koncentrujące się na tym jednym aspekcie biografii poety, jak na przykład w syntetycznym szkicu Aldony Senczkowskiej „Imię moje Ruina” - życie Zygmunta Krasińskiego w europejskich uzdrowiskach (w: Kultura uzdrowiskowa na Dolnym Śląsku w kontekście europejskim, t. 1, pod red. B. Płonki-Syroki i A. Kaźmierczak, Wrocław 2013).

2 Szeroko dokumentują to zjawisko prace Jana Pacholskiego (Pobyty w uzdrowiskach ślaskich w literaturze niemieckiej), Krzysztofa Pawła Woźniaka (Wyjazdy polskiego ziemiaństwa i burżuazji „do wód” w świetle pamiętników i wspomnień XIX wieku), Agaty Wdowik („Ciało się zdrowszym czuje i weselsza dusza”. Polskie świadectwa podróży do Spa w drugiej połowie XVIII wieku), Moniki Matysiak („Ci tańcza, ci się patrza, a wszyscy weseli. Nawet chorzy na chwile chorób zapomnieli” - życie towarzyskie i rozrywki w XIX-wiecznych uzdrowiskach [1795-1863]) i innych autorów, opublikowane w tomie Kultura uzdrowiskowa na Dolnym Śląsku w kontekście europejskim. Obszerny materiał przedstawił Ryszard Kincel w książce U szląskich wód (Racibórz 1994). 
geografia: Karlsbad i Marienbad, Baden i Kissingen, Heidelberg, w którym miał katedrę i prowadził praktykę słynny lekarz Krasińskiego - Maximilian Joseph von Chelius. Wyjazdy do kąpieli morskich - atlantyckich i nad Morze Śródziemne.

Krasiński w swych listach zostawił niewiele szczegółów bywania „u wód”3. Znacznie więcej o pobytach w uzdrowiskach europejskich pisała Eliza Krasińska. Jeszcze jako Eliza Branicka donosiła z Karlsbadu w 1838 roku:

Wstajemy wcześnie i jak przystało łykamy wodę, spacerujemy, potem śniadanie i kilka godzin, w których można coś niecoś zrobić. Trzy razy w tygodniu kąpiel, w pozostałe dni składamy lub przyjmujemy kilka wizyt.

$\left(\right.$ LEK I 101) ${ }^{4}$

Już podczas wspólnych pobytów w latach czterdziestych i pięćdziesiątych XIX wieku w Baden (dziś: Baden-Baden), które opisuje jako „szmaragdowe gniazdko", otoczone lasami pachnącymi żywicą (LEK II 43), dostrzega wyjątkowość tego miejsca:

Prawdą jest, że Baden nie ma wcale pretensji, by być czymś innym jak tylko gniazdkiem zagubionym w lasach i górach. Jego istotą jest brak hałasu, ruchu, ożywienia, życia ruchliwego i hałaśliwego. Toteż nie udaje, że jest czymś innym. Ja jednak dosyć lubię ten rodzaj samotności w środku cywilizowanego świata - ma się korzyści miasta, tzn. pocztę, wiadomości, gazety, a jednocześnie całkowitą niezależność absolutnego ustronia.

(LEK II 117)

Są tu oczywiście i inne atrakcje, co świadczy, iż Baden ma typowy charakter dziewiętnastowiecznego luksusowego kurortu. „Tu się bawią, urządzają bale, [...]” (LEK II 148), odbywają się loterie i koncerty (LEK II 341):

Baden to prawdziwy klejnot mieniący się w słońcu tysiącem świateł, tysiącem kolorów, każda przechadzka to nowa rozkosz; [...] czasem razem jeździmy konno, wieczorem chodzimy posłuchać muzyki, oglądamy nowe i stare piękności i wciąż zmieniający się tłum wytwornych ludzi.

(LEK III 128)

3 Oprócz wymienionych już prac można dodać jako kontekst dla przedstawianych rozpoznań ujęcia odnoszące się do czasów nieco późniejszych: E. Ihnatowicz, Kraszewski „u wód”, w: Obrazy kultury polskiej w twórczości Józefa Ignacego Kraszewskiego, pod red. B. Czwórnóg-Jadczak, Lublin 2004; D. Opaliński, „Dusza się tu i oddrętwia i młodnieje". Wrażenia Polaków z podróży do kurortów europejskich w XIX wieku, w: Europejczyk w podróży 1850-1939, pod red. E. Ihnatowicz i S. Ciary, Warszawa 2010.

4 Wszystkie cytaty z korespondencji Elizy Krasińskiej pochodzą z wydania: Świadek epoki. Listy Elizy z Branickich Krasińskiej, t. 1-4, z rękopisu odczytał, wybrał, skomentował i wstępem opatrzył Z. Sudolski, przeł. U. Sudolska, Warszawa 1995-1996. Po skrócie literowym LEK cyfry rzymski oznaczają tom, arabskie - numer strony. 
W wieku XIX, jak pisze Bożena Płonka-Syroka, ukształtowały się dwa modele uzdrowiskowe: francuski, wsparty splendorem i luksusem miejsc, oferujący obok działalności leczniczej także szeroko rozbudowaną sferę towarzysko-kulturową oraz model niemiecki, przyporządkowany zabiegom, dla którego podstawą:

[...] była terapia naturalna (Naturheilkunde), opierająca się na przekonaniu o niezwykłych właściwościach leczniczych wszelkiego rodzaju surowców naturalnych, w których znajdować się miała specyficzna dla nich niematerialna siła, oddziałująca terapeutycznie na organizm. Szczególne właściwości lecznicze przypisywano przy tym wodzie, którą obficie stosowano we wszystkich możliwych postaciach, od kąpieli, poprzez okłady, do pryszniców, a także w formie pitnej. ${ }^{5}$

Warto dodać, że niemal do końca XIX wieku zalecano picie bardzo dużych ilości wody ${ }^{6}$. W korespondencji Krasińskiego znajduje się wiele przykładów łączenia balneoterapii z hydroterapią, jak ten oto: „Temu trzy dni, jakem tu [w Heidelbergu - A.B.] się zjawił. Będę wody brał ze trzy tygodnie, potem pojadę do morskich kąpieli na dwa tygodnie, [...]” (LAS 474) ${ }^{7}$. Wcześniej w jednym z listów pojawia się następująca relacja: „[...] jadę na kurację dosyć niebezpieczną, ale która zdaje się, rozstrzygającą będzie. Zależy na mocnych potach i na włażeniu w lodowatą wodę, wśród tych potów" (LG 127).

Po latach, jak w liście z 1851 roku, pojawią się tony bardziej krytyczne wobec podejmowanych terapii:

5 B. Płonka-Syroka, Uwarunkowania medyczne i społeczne kształtowania się standardu kultury uzdrowiskowej w Europie czasów nowożytnych, w: Kultura uzdrowiskowa na Dolnym Ślasku w kontekście europejskim, s. 50. W świetle tej klasyfikacji Baden, w którym bywali Krasińscy, miałoby cechy łączące dwa modele uzdrowiska: leczniczy i towarzyski.

6 Choć i tak, jak zauważa Woźniak, „dopiero na przełomie XVIII i XIX wieku, za sprawą dra Dawida Bechera z Karlsbadu, dokonała się zasadnicza zmiana w balneoterapii i hydroterapii, polegająca przede wszystkim na znacznym ograniczeniu wody pitej przez kuracjuszy (z 20-60 do 5-10 kubków dziennie) i wydatnym skróceniu czasu kąpieli (z 4-5 godzin do 30-6o minut)" (K.P. Woźniak, dz. cyt., s. 260).

7 W taki sposób odsyłam do epistolografii poety. Skrót literowy odnosi się do konkretnego zespołu epistolarnego, cyfry rzymskie oznaczają numer tomu, arabskie - strony: LJL - Z. Krasiński, Listy do Jerzego Lubomirskiego, oprac. i wstępem poprzedził Z. Sudolski, Warszawa 1965; LDP - Z. Krasiński, Listy do Delfiny Potockiej, t. 1-3, oprac. i wstępem poprzedził Z. Sudolski, Warszawa 1975; LAS - Z. Krasiński, Listy do Adama Sottana, oprac. i wstępem poprzedził Z. Sudolski, Warszawa 1970; LG - Z. Krasiński, Listy do Konstantego Gaszyńskiego, oprac. i wstępem poprzedził Z. Sudolski, Warszawa 1971; LRA - Z. Krasiński, Listy do różnych adresatów, t. 1-2, oprac. i wstępem poprzedził Z. Sudolski, Warszawa 1991; LAC - Z. Krasiński, Listy Augusta Cieszkowskiego, Edwarda Jaroszyńskiego, Bronisława Trentowskiego, t. 1-2, oprac. i wstępem poprzedził Z. Sudolski, Warszawa 1988. 
W sierpniu wyprawiono mnie do morskich kąpieli. Brałem je do 20-go okt[obra]. Dorznęły mię. Ledwom ócz nie stracił. Wzrok pogmatwał się i popsuł od nich. Rozdrażń mózgu niesłychana. Nogi nawet odjęła. [...] Stałem się r u i n ą ciała.

(LAS 562-563)

Biografia Krasińskiego - to więc z konieczności życie w uzdrowiskach, i w tym porządku można także prześledzić dokonujący się w pierwszej połowie XIX wieku proces przemian uzdrowisk: od pozbawionych wygód miejsc (z lat trzydziestych XIX wieku) po oferujące szeroki zakres rozmaitych usług i luksusów bady (relacje $\mathrm{z}$ lat czterdziestych i pięćdziesiątych XIX wieku). Znawcy zagadnienia podkreślają także dokonującą się demokratyzację uzdrowisk i kultury uzdrowiskowej w XIX wieku, choć lokują jej intensyfikację w drugiej połowie stulecia ${ }^{8}$. Krasiński dużą część swego życia spędza w sławnych europejskich uzdrowiskach, wszakże - w przeciwieństwie do wielu bywalców „u wód” - jest przede wszystkim pacjentem, poddaje się kuracjom, zwłaszcza modnym w epoce kąpielom oraz piciu wody.

\section{W BADACH}

Z lat trzydziestych XIX wieku pochodzi świadectwo epistolarne, dokumentujące modną i obejmującą coraz szersze warstwy społeczeństwa kurację wodami. W 1836 roku Krasiński był w Marienbadzie i Karlsbadzie i stamtąd słał do Adama Sołtana obserwacje wskazujące na ową zmianę charakteru uzdrowisk, które z miejsc dostępnych najzamożniejszym stają się otwarte dla szerokich grup społecznych - tej zmiany on, arystokrata, nie aprobował (stąd wyraźna antysemicka nuta pobrzmiewająca $\mathrm{w}$ tym fragmencie epistolarnym):

[...] szczególne próbki towarzystwa warszawskiego fashionable za dni teraz płynących przechadzają się po Karlsbadach i Marienbadach; przechrzty, celnicy, ludzie spanoszeni od 1831 r. arendą wziętą od rządu nad wódką, tabaką i towarami, ludzie zowiący się Szmulami [...], gadający mi o swoich kucharzach, apartamentach, o balach dawanych w Zamku pod Kolumną Zygmunta, [...]. Lecz w Karlsbadzie, w Marienbadzie już wytrzymać nie potrafisz - tam nie Ukraina, nie Wielkopolska, nie Litwa, ale Warszawa się wylała. Wylały się pomyje, co zostały na dnie w tej beczce, braha skiśniała gorzelników i piwowarów.

(LAS 97-98)

Kilka lat później poeta pisał do Delfiny Potockiej z Wildungen, kreśląc z duża dozą ironii taki obraz miejsca pobytu kuracyjnego:

[...] miasteczko o niewielu domach, o jednej tylko ulicy, długiej, brukowanej gwoździami z kamieni, a pełnej błota, brudu, słomy i stosów śmieci, tak jak u nas po mia-

B. Płonka-Syroka, Uwarunkowania medyczne i społeczne..., s. 51 i n. 
steczkach żydowskich. [...] O wiorstę od miasteczka, w pobliżu źródła mineralnej wody, wznosi się jedyna w tej puszczy gospoda, podobna z położenia na wierzchołku góry i z nędznej powierzchowności do Graefenbergskiej. W niej dwa mamy pokoiki. Od tej gospody dwie ulice lipowe się w dół rozchodzą przeciwnym kierunkiem: jedna ku miasteczku dąży, druga zstępuje do źródła pod drewnianą altaną bijącego i opatrzonego parodią kurhauzu, ulepioną z drewna i gliny, w której jest sala, a tam co niedziela [...] - zgromadza się okoliczna szlachta, to jest ekonomy, komisarze z dóbr okolicznych, niektórzy mieszczanie z Kassel z żonami, z córkami, piją, jedzą, śpiewają, wrzeszczą, tańcują, nawet w ruletę grają: [...] Z tego możesz pomiarkować, jakie tego B a d u przepychy i wygody.

(LDP I 297-288)

Ale $\mathrm{w}$ przeciwieństwie do licznych świadectw z epoki - Krasiński nie rozpisuje się zbyt szeroko nad formami życia kuracyjnego i towarzyskiego „u wód”. Owszem, nie szczędzi szczegółów kuracji, lecz umieszcza je nie tyle w medycznych, ile pozamedycznych zgoła ramach dyskursywnych: przede wszystkim antropologii romantycznej, wychylonej ku historiozofii i eschatologii. Można to prześledzić na obszernym materiale, $\mathrm{z}$ różnych miejsc kuracyjnych pobytów. Kiedy pisze z Wildungen do Delfiny Potockiej, obmierzłym wydaje mu się to miejsce, przeniknięte grobową atmosferą, rozpaczą i beznadzieją (LDP I 296). Takim jest to miasteczko, bo nie ma w nim tej, którą kocha. I z tego „złowrogiego miejsca” (LDP I 295) śle swoje przemyślenia filozoficzne - o „płciowości”, czyli rozdzieleniu bytu, wszędzie ją dostrzega, widząc zarazem, jak z tych dysonansów układać się zaczyna harmonia. Przyszła harmonia. I to jest owa rama historiozoficzno-eschatologiczna, w której Krasiński umieszcza, by tak rzec, narrację o swoim istnieniu. Zdaje się, że można zaryzykować twierdzenie, że kuracja jest pewnym ogólniejszym symptomem „rozstrojenia” i romantycznego „ja”, i planety - przeto kuracje wodne, jak planetarne niepokoje, prowadzić mają ku przyszłej harmonii, ku przezwyciężeniu choroby. Z dysonansów rozpoznawanych w skali mikro- i makrokosmosu wypływają daleko ogólniejsze wnioski. Znaczyć to może i tyle, że kuracje Krasińskiego to - toutes proportions gardées - paralelne do ogólniejszych procesów dziejących się w historii, serie podejmowanych prób przezwyciężenia zasadniczego kryzysu epoki ${ }^{9}$, rozpoznawanego, owszem, w płaszczyźnie egzystencjalnej, lecz widzianego przy tym w perspektywie nieomal kosmicznej (zwłaszcza listy do Augusta Cieszkowskiego z czasów Wiosny Ludów dostarczają tu bogatego materiału egzemplifikacyjnego). Do tej kwestii przyjdzie jeszcze wrócić.

9 Kryzys ów to przenikające całą Europę lat czterdziestych XIX wieku niepokoje społeczno-polityczne, zapowiadające Wiosnę Ludów. Zob. L.B. Namier, 1848. Rewolucja intelektualistów, przeł. A. Ehrlich, Kraków 2013. 


\section{PACJENT I JEGO LEKARZ}

Krasiński ufał kuracjom doktora „niemieckiego, głębokiego i oświeconego”, jak pisał o Maximilianie Josephie Cheliusie (w listach obocznie pojawia się zapis fonetyczny nazwiska: „Chilius”). Ten znany chirurg i okulista, profesor uniwersytetu w Heidelbergu, był rodzinnym lekarzem poety, a wiele świadectw epistolarnych Krasińskiego i jego żony zaświadcza o niezwyczajnym z dzisiejszej perspektywy oddaniu pacjentowi, będącemu wszakże standardem w epoce. Relacja Chelius - Krasiński, lekarz - pacjent, w dużym stopniu towarzyska, oparta jest na przynależności do

[...] tego samego świata pojęć, który dla obydwu stron relacji terapeutycznej jest w podstawowym sensie zrozumiały. Nie dysponując w latach 1830-1850 żadnymi w zasadzie metodami skutecznej terapii i budując dopiero system pojęć nowoczesnej fizjologii i patologii, europejscy lekarze skierowali do grupy swoich zamożniejszych pacjentów bogatą ofertę pielęgnacyjną i profilaktycznąa

- pisze znawczyni problematyki.

W korespondencji poety oraz w listach Elizy z Branickich Krasińskiej znajdziemy wiele opisów zaleceń terapeutycznych Cheliusa, zaś Heidelberg i pobliskie Baden przez wiele lat staną się miejscami pobytu rodziny Krasińskich - i terapii wodnych przede wszystkim. Pamiętając o tym, że relacje poety (i jego żony) są świadectwem $z$ drugiej ręki, do której nie mamy bezpośredniego dostępu, możemy z zachowaniem pewnej ostrożności wyprowadzić z zapisów epistolarnych niektóre ogólniejsze przesłanki dotyczące charakteru i sposobu leczenia. Chelius, co warto podkreślić, leczył ciało, dostrzegając wszakże „zakorzenienie" choroby w duchowości pacjenta, jakkolwiek sam poeta - przypomnijmy - sytuował swoje stany choroby niemal wyłącznie w kategoriach pozasomatycznych. Ale też z zadziwiającą regularnością donosił swym korespondentom o diagnozach i sposobach leczenia podejmowanych przez Cheliusa. Ta relacja dotyczy choroby duszy, odbijającej się na funkcjonowaniu ciała:

Wczoraj w wieczór Chiliusowi się skarżyłem na stany prawie szaleństwa smutnego, które mną owładają. Słuchał, słuchał, a potem poważnie rzekł: „Oczywiście wszystkie symptomata hipochondrii w silnym stopniu”. Radził, po 17-stu butelkach kissingen, winogronową kurację.

(LDP III 102)

Jużem butelkę kissingen wpakował dziś do mózgu, ale jakoś niewiele wpływu wywołała.

(LDP III 125)

10 B. Płonka-Syroka, Kształtowanie się relacji lekarz-pacjent jako stosunku o charakterze dyrektywnym - próba charakterystyki procesu, w: Proces modernizacji nauk przyrodniczych $w$ historii i historiografii nauki, pod red. B. Płonki-Syroki, Wrocław 2003, s. 114. 
W listach Krasińskiego przewijają się frazy podobne do wyżej przytaczanej. Woda wnika do konkretnego narządu wewnętrznego: do mózgu, do żołądka, do płuc, do serca, pobudza pracę narządu i zarazem wywołuje dezorganizację, co rzutuje na dysharmonię całego organizmu, która winna wszakże ostatecznie prowadzić do harmonii, do wyleczenia: „I dziś kissingen piłem, krew bije do głowy, ale na duchu nieco lepiej” (LDP III 130); „[... ] i piszę z czterema szklanicami wody kissingskiej w piersiach” (LDP III 110); „I dziś fatalnie mi źle, nerwowo, rozdrażniono, nieznośnie - wody się burzą" (LDP III 401).

Leczenie dotyczyło oczywiście cielesnych przypadłości, nękających poetę:

Chilius mnie dziś na wszystkie boki opatrywał, dotykał, macał. Znalazł wątrobę nabrzmiałą, i ślad, że się cyrkulacja najgorzej odbywa, że zaś do tego liszaje były, więc kazał by tu ze 16 butelek kissingen naprzód, a potem na kąpieli 15 lub 20 do Akwizgranu i popijanie lekkie siarką [...].

(LDP III 381)

Nieustannie przewijają się w listach informacje o kuracjach wodą i zalecanych kuracjach wodnych (kąpiele). Po latach terapii, Krasiński z pacjenta przeistacza się w „lekarza” - Delfiny Potockiej i w listach do niej próbuje dyskursu medycznego swej epoki:

Jeśli wody zaczniesz pić, Dialy, przed moim przyjazdem, proszę cię i błagam, byś od jednej szklanki, najwięcej dwóch zaczęła i tak piła dwie tylko przez cztery, pięć dni. Później trzy, znów przez cztery dni, wreszcie c z t e r y, a nigdy więcej, aż do końca. Nie w łóżku, nie w pokoju pić masz, bo inaczej lepiej nie pij, ale chodząc i k w a $\mathrm{d} r$ a n s e m przynajmniej przedzielając szklankę od szklanki, a dopiero w trzy kwadranse od ostatniej kawę pijąc, jeśli skutku nie ma, w pół godziny w przeciwnym razie. Dalej fruktów [ani] kwasów nic a nic. Zasypiania żadnego we dnie, po wodach zaraz ni po obiedzie, aż w nocy. Inaczej nie pij, bo będą trucizną, a gdy zachowasz, co mówię, będą cielesnym zbawieniem.

(LDP II 667)

Warto kontekstowo wskazać, że w korespondencji Elizy z Branickich Krasińskiej pojawiają się bardzo podobne formuły, odnoszone do wodnych kuracji doktora Chiliusa. W 1849 roku, kiedy Krasińscy przebywają w Baden, kuracji poddaje się żona poety. Pisała o „pracy nad zdrowiem” w listach do Katarzyny Potockiej:

Żyjemy więc pod znakiem pracy nad zdrowiem. Ja mam zacząć kurację z kilka dni, a ponieważ jest to ostatnia kuracja przed długą przerwą, poddaję się z rezygnacją na wypicie dwóch szklanek słonej i żelaznej wody. Dzieci będą brały orzeźwiające kąpiele.

(LEK II 224)

Na razie jestem uwiązana w Baden [...] przez kurację, na którą mnie skazano [...] Są to kąpiele żelazne, wody żelazne, chce się mnie hartować i zestalić przeciw zimowym 
mrozom [...] dzieci biorą słone kąpiele, a bona wody homburskie i kąpiele mydlane.

(LEK II 224)

Eliza Krasińska w swoich listach pozostawiła ciekawe informacje dotyczące kuracji aplikowanych poecie przez Cheliusa, ukazujące przy tym romantyczną relację lekarz - pacjent. Chelius zalecał stopniowe oddziaływanie, w zależności od obserwowanego działania poszczególnych leków („Ta kuracja jest nie tylko ze strony lekarza dziełem nauki i zaangażowania uczuciowego, ale wymaga również ze strony pacjenta wytrwałości i cierpliwości”; LEK II 305). Jakie to były medykamenty - nie wiemy, ale i tu dostrzec można nowe stanowisko, zapewne przezwyciężające typową dla epoki niechęć do leków" ${ }^{11}$. Chelius chce chorobę pokonać, dążąc „do odcięcia jej korzenia” (LEK II 305), pragnie oddziaływać na chory organizm wieloaspektowo, pobudzając go do reakcji, co jest typowe dla postępowania medycznego w epoce:

Każe mu brać różnego rodzaju leki, kąpiele, nacierania, słowem stosuje kurację bardzo skomplikowaną, bardzo wyważoną, często modyfikowaną i zmienianą zgodnie z odniesionym wrażeniem. Chelius mówi jeszcze, że należy postępować bardzo ostrożnie, że zbyt nagłe zastosowanie jakiegoś środka może być jak najgorsze w skutkach [...].

(LEK II 306)

Chelius zalecił na początek picie soków z ziół i serwatki, kąpiele badeńskie z solą Kreuznach, a później, jeśli uzna za stosowne, trochę Homburga i Kissingen; wszystko bierze się u niej ze złego krążenia krwi, które trzeba leczyć.

(LEK II 336)

Jak widzimy, Chelius chce skutecznie leczyć, oczywiście zgodnie z ówczesnymi standardami i stanem wiedzy medycznej. Jest przy pacjencie, obserwuje jego reakcje - i na podstawie empirycznych obserwacji modyfikuje kurację, polegającą na oddziaływaniu na organizm. Zapewne był eklektykiem. Obok metod przypisywanych medycynie somatycznej, stosował homeopatię, typową dla medycyny romantycznej ${ }^{12}$. Jak czytamy w jednym z listów, Krasiński

11 „Charakterystycznymi dla pierwszej połowy wieku są wielkie odkrycia nowych, silnie działających substancji wyizolowanych z roślin, którym towarzyszył niemal absolutny sceptycyzm i niewiara lekarzy w jakąkolwiek skuteczność terapeutyczną. W umysłach lekarzy ugruntowało się bowiem przekonanie, [...] że nie należy przeszkadzać lekarstwami poprawnemu przebiegowi choroby [...]" (Historia medycyny, pod red. T. Brzezińskiego, Warszawa 200o, s. 360).

12 Pisała Płonka-Syroka: „Pojęcie choroby miało w doktrynie Hahnemanna charakter niematerialny. Była ona interpretowana jako zaburzenie duchowej siły, utrzymującej przy życiu ludzki organizm. [...] Terapia [...] była zwrócona w stronę tej duchowej siły i jej zakładanym celem było przywrócenie prawidłowego poziomu kontroli, sprawowanego przez tę siłę, nad przebiegiem procesów somatycznych” (B. Płonka-Syroka, Niemiecka medycyna romantyczna, Warszawa 2007, s. 259). Warto dodać, że o dok- 
Czuje się gorzej od kilku dni z powodu lekarstwa, które wydaje się niezgodne z jego naturą i chociaż zażyte w homeopatycznej dawce, zaszkodziło mu. Chelius, którego ten delikatny organizm zdumiewa, mówi nam, że trzeba zachować jak największą ostrożność w leczeniu, należy studiować efekt każdego lekarstwa, ażeby było wiadomo jak go zażywać.

(LEK II 310)

Przyznaję, iż jestem zadowolona, gdy mogę leczyć dzieci homeopatią, która nie podnieca nerwów, nie osłabia, nie narusza źródeł witalnych. Gdy jest się bardzo niespokojnym, te kilka kropel bezbarwnej i bez smaku wody wydają się niczym, a jednak, gdy widzi się skutek tej niewidzialnej przyczyny, trudno nie uwierzyć w ich moc.

(LEK III 215)

W innym liście Elizy Krasińskiej pojawia się wzmianka o charakterze ogólniejszym. To swoista charakterystyka podstaw sztuki lekarskiej Cheliusa:

[...] jak mówi Chelius, który przez 40 lat praktyki widział dużo chorób, nie wolno niczego lekceważyć. Nieuleczalne i straszne cierpienia biorą się z lekkich objawów, które zostały zaniedbane. Toteż jego metoda polega na zatrzymaniu każdej choroby w zarod$\mathrm{ku}$, zanim się rozwinie [...].

(LEK II 317)

Jak przejawia się ta metoda w praktyce? Oto opis leczenia choroby oczu Krasińskiego:

Dzisiaj Chelius przyłożył mu żegadło, gdyż chroniczne zapalenie powiek nie ustępuje pod wpływem żadnego lekarstwa i stanowi ciągłe zagrożenie; któregoś dnia nałożył mu rodzaj plastra $\mathrm{z}$ belladonny na plexus solaris [...].

(LEK II 313)

\section{CHOROBA, KURACJE, CIAŁO}

W miejscach pobytu kuracyjnego życie Krasińskiego płynie dość monotonnie, jeśli zawierzyć wyłącznie jego listom. Poza samymi kuracjami - cóż takiego się dzieje? Spacery, myślenie i pisanie listów. Przemyślenia i pisanie niewątpliwie $\mathrm{w}$ jakimś przedziwnym związku z doświadczaniem choroby, ujmowanej - co dla zwolennika dialektyki, jakim jest Krasiński, wydaje się charakterystyczne - w dwu porządkach, duchowym i cielesnym ${ }^{13}$. Choruje dusza i ciało,

trynach medycyny romantycznej w odniesieniu do Adama Mickiewicza interesująco pisał Leszek Libera (Mickiewicz i medycyna, w: tegoż, Mickiewicz i medycyna. Szkice romantyczne, Zielona Góra 2010).

13 Pisał o tym obszernie Marek Bieńczyk w książce Czarny człowiek. Krasiński wobec śmierci (Warszawa [1990]). Z perspektywy teatralizacji choroby, której somatycznym wykładnikiem jest histeria (będąca z kolei w ścisłym w związku z melancholią), przyglądał się Krasińskiemu, sięgając po narzędzia psychoanalizy Michał Paweł Markowski w szkicu Krasiński: na scenie histerii (w: tegoż, Życie na miarę literatury. Eseje, Kraków 
stąd pobyty u wód mają wzmocnić tak duszę, jak ciało. Choruje „ja” romantyczne, bo choroba zawładnęła planetą. Korespondencje między ,ja” a kosmosem są tu rozpoznawane na wzór systemu nerwowego, i ta paralela przewija się w całej korespondencji poety. W jednym $\mathrm{z}$ listów pisanych do Delfiny Potockiej znalazło się charakterystyczne rozpoznanie istoty owej paraleli:

Boleść jakaś nudząca a ostra wpakowała mi się w sam plexus solaris. Do tego gorąco okrutne, rozwiązujące nici żywota i z kłębka węźlanego rozpuszczające je w świat, w wszechświat, tak iż mi się wydaje, że koniuszczki moich nerwów już gdzieś na księżycu, słońcu, planetach, gwiazdach, drogach mlecznych i że coraz dalej płyną, coraz głębiej się nurzą, coraz szerzej się rozchodzą, a ciągną za sobą to, co stanowi moje Ja, i to J a moje, pochylone, za nimi idzie, da się im rozdzielać, rozwiewać, roznicestwiać jak para, jak pył, jak Nic!

(LDP III 413)

Dezorganizacja „ja” grozi więc jakimś rozproszeniem bytu, ujmowanym w kosmicznych sceneriach przypominających wizje Jean Paula. Tej sytuacji - groźnej dla tożsamości „ja” - należy przeciwdziałać. Mówiąc językiem poety „zdechłe nerwy” należy przywrócić do życia tak, by mogły „galwanizować” „muszkuły” (LDP III 413). Krasiński jest niewątpliwie wyznawcą takiego rozumienia kuracji, które jest charakterystyczne dla standardu niemieckiej medycyny romantycznej: choruje ciało i dusza, zaś z kuracji wzmocniony ma wyjść co prawda cały człowiek, ale „wyzdrowienie” duszy jest ważniejsze niż powrót do zdrowia ciała. O tym czytamy w jednym z listów z późniejszej kuracji heidelbergskiej z 1847 roku: „Nie wiem, co mi się dzieje, ale czuję jakoby trupa duszy w trumnie ciała, i te dwie części mojej całości ducha oczywiście żywego złożyć nie mogą" (LDP III 411). Dlatego trzeba pić dużo wody, po kilkanaście butelek dziennie - zgodnie z ówczesnymi zaleceniami lekarskimi. Tylko w taki sposób można pokonać chorobę: toczącą ciało i dotykającą duszy. W jednym $\mathrm{z}$ listów z kuracji w 1841 roku pisał:

W Wildungen tylko 12 także wypiłem [„,butelek kissingskich”, jak wcześniej czytamy - A.B.], a już mi bardzo pomogły. Wierz mi, Didysz, kiedym Cię tak nudził moją

2009). Oczywiście literatura na temat różnych aspektów choroby (w tym słynnych neuroz) i jej tekstualizacji w twórczości Krasińskiego jest obszerna. Wskażę inspirujące ujęcia nowsze, choć chciałbym powiedzieć, że moje myślenie idzie innym torem niż przedstawiane w następujących pracach: A. Kubale, Dramat bólu istnienia w listach Zygmunta Krasińskiego, Gdańsk 1997; M. Chołody, Ciało - dusza - duch. Dyskurs cielesny $w$ romantyzmie polskim (fragmenty), Poznań 2011; D. Danek, Istnienie z kontr-wzajemnością. Krasiński i dzieciobójstwo, w: tejże, Śmierć wewnętrzna. Literatura wświetle doświadczenia psychoanalitycznego, Gdańsk 2012; M. Bizior-Dombrowska, Śmiertelna nuda Krasińskiego oraz M. Barańska-Guz, Depresja i melancholia w listach Zygmunta Krasińskiego, w: Zygmunt Krasiński. Dylematy egzystencji - problemy biografii, pod red. M. Bizior-Dombrowskiej, Torun 2014. 
melancholią, z choroby to pochodziło. Prawda, że choroba ze smutku. U mnie rozpacz pochodzi z duszy, z żalów i trosk, ale niemoc przy rozpaczy, ślamazarność przy bólu moralnym idzie prosto z ciała. Czuję konieczną potrzebę jeszcze przekissingowania się, użyję na to czasu pokuty pozostałej mi do dopełnienia przepisów.

(LDP I 328)

Wcześniej - w 1836 roku - podczas pobytu w Graefenbergu zastosował się do kuracji Vincenza Priessnitza ${ }^{14}$. Tak pisał - zauważmy, że w tonacji ironicznej - o tej kuracji:

Co dzień rano o pół do 5-tej budzony bywam [...], obwijają mnie w kołdry, jak dziecię w powiciu lub umarłego w chusty śmiertelne, tak że nogą ni ręką ruszyć nie mogę. Ten stan szczęśliwości trwa do trzech godzin, podczas których potnieję jak gdyby po frykcjach merkurialnych. Następnie rzucam się w wodę zimną jak lód. Wieczorem taka sama anegdota. O ćwierć mili stąd, w lesie, jest kaskada, tam trza się rozebrać do nagiego i stać pod strugą wody pięć minut. Na śniadanie szklanka wody i chleb, na kolację idem (jak poprzednio), na obiad zupa i sztuka mięs. Zresztą przez cały dzień każą pić wody do 20-stu szklanek i chodzić od świtu do zmroku.

(LAS 105)

Ta kuracja przyniosła znaczne osłabienie organizmu, o czym Krasiński w podobnej stylistyce donosi Adamowi Sołtanowi; możemy tu wszakże dostrzec, iż kuracja była stosowana wobec całego organizmu, miała poprawić funkcjonowanie całości, która obecnie - jako całość właśnie - znajduje się w stanie kryzysu:

Takiem osłabiony tymi gwałtownymi wstrząśnieniami całego mojego organizmu, że ledwo pisać mogę. [...] w nogach takie osłabienie, jak gdybym kilka dni bezprzestannie szedł po mil kilka na dzień; w mózgu niedołężność i ciężkość, tak że nawet ściśle myśli zebrać nie mogę. Zgoła jestem do niczego. Sauvan obiecuje najpomyślniejsze skutki. Tutejszy mistrz wody zimnej, Prysznitz, to samo twierdzi, ale to jest questio resoluta, jak ta o nieśmiertelności duszy.

(LAS 106)

Marek Bieńczyk zauważył, że Krasiński stworzył szczególnego rodzaju dyskurs o ciele i chorobie. Ciało (mikrokosmos) - w którym poszczególne organy stanowią dynamiczną całość, oplecioną „systematem nerwów” - jest zanurzone w sieć relacji z naturą, kosmosem (makrokosmosem), i ta relacja ma również charakter dynamiczny. Ciało potrafi odczuć katastrofy, zaburzenia, zaś owe katastrofy wpływają także na ciało, na stan „mózgu” i „nerwów” konkretnej jednostki, w tym wypadku Krasińskiego, odczuwającego rozmaite „podrzuty” historii. Kiedy zaś odczuwa je, sam reaguje podobnymi zachowaniami ciała: konwulsjami, uderzeniami krwi do mózgu, rozmaitymi i o różnym natężeniu

14 Zob. zwięzłe informacje w rozdziale Wodolecznictwo Priessnitza i Kneippa, w: Historia medycyny, s. 422-423. 
bólami. Choroba Krasińskiego ${ }^{15}$ to stan, w jakim znajduje się organizm - jeden narząd potrafi rozregulować całość - i zarazem proces, paralelny do zjawisk dziejących się w naturze, kosmosie, historii. Ma rację autor Czarnego człowie$k a$, konstatując: „Krasiński traktuje i rozpoznaje swoje życie jako chorobę”16 - i dalej: „Obraz egzystencji i doznania chorobowe występują w nieoczekiwanym związku jednorodności” ${ }^{17}$. Co mogłoby znaczyć, iż swoje konkretne dolegliwości somatyczne rozpoznaje w kontekstach dyskursywnych, jakie wypracowała medycyna romantyczna. Relację ciała i jego organów rozpoznaje się przez inną relację: ciała do myśli (woli); ciało jest bezwolne, pozostaje w kryzysie, bo taki jego stan narzuca pogrążony w zamętach dziejącej się historii świat. System „nerwów” i „mózg” - odbiera ów chaos świata bezpośrednio. I równie bezpośrednio reaguje organizm: stale czytamy o rzutach krwi, drganiach ciała, różnego rodzaju bólach somatycznych. Efektem jest melancholijne znieruchomienie, stupor. W jednym z listów do Delfiny Potockiej z 1847 roku znalazła się wymowna paralela:

Budowa mózgu mojego rozpada się coraz lepiej. Nazywam jej rozpadkiem melancholię. Coraz głębiej wpaja się w organa myśli mojej i niszczy je. Trucizna istna. Całe ciało ociężywa, zbezruchamia się, a w tym grobie z kamienia myśl myśli czarno, smętno, tęskno, nieznośna sobie, a nie mogąca ciała poruszyć.

(LDP III 417)

Takie rozpoznanie przenoszone jest następnie na relację ciało - kosmos przez medium historii; ciało zacznie zamieniać swoją „martwotę” na „życie”, wprawione zostanie w „drgania”, o ile odczuje rytm zmiany kosmosu ${ }^{18}$. Krasiński uruchamia tu specyficzny dyskurs historiozoficzny, odnoszący się do mającej nadejść „trzeciej epoki”"

Jużci oczywiście cuda się na ciałach, nie na duszach okazują, [...] Ciała nasze drgać będą tak drganliwie, że wiew z drugiej półkuli je poruszy, że promień z Syriusza je

15 Choroby Krasińskiego, jak dowiodły badania Bieńczyka, przedstawiane w Czarnym człowieku..., trwale zakorzenione są w doświadczaniu śmierci, obejmującym całość bytu. Zwracał też uwagę na ten aspekt myśli i wyobraźni autora Irydiona Wojciech Gutowski w szkicu W kręgu romantycznej fenomenologii śmierci (w: Style zachowań romantycznych, pod red. M. Janion i M. Zielińskiej, Warszawa 1986).

16 M. Bieńczyk, dz. cyt., s. 81.

17 Tamże, s. 84.

18 Zauważmy na marginesie, że w wyobraźni Krasińskiego dyskurs o ciele i chorobie wchłania elementy języka łączącego Naturphilosophie z odkryciami fizyki, zwłaszcza zjawiska elektryczności.

19 Koncepcję „trzeciej epoki” - obejmującą różne aspekty percypowanych zjawisk, od życia codziennego po wizje eschatologiczne - omawiam w książce Poezja „trzeciej epoki”. O twórczości Zygmunta Krasińskiego w latach 1836-1843 (Lublin 2009). 
wprawi w ból lub ukojenie, że na krzyk: do broni, trupy będą zmartwychwstawać itd., itd. Czy nie czujesz, że ku temu się nasze nerwy mają?

(LDP III 418)

To, chciałoby się rzec, typowy przejaw dyskursu ciała i choroby, ujmowanych w paralelnej relacji. Można więc podkreślić, że choroba ciała to dla Krasińskiego przejaw innego zaburzenia pochodzącego $\mathrm{z}$ innych porządków: natury, historii, kosmicznej zmiany, które zapowiadają rozmaite zdarzenia, niezależnie czy będzie to wybuch wulkanu, czy wybuch rewolucyjny. Ciało odczuwa owe „zaburzenia” uprzedniej harmonii albo też profetycznie odbiera w swym stanie kryzysu - a tym jest choroba - zapowiedzi przyszłego pojednania. Ciało cierpi, odczuwa ból, choruje i tym samym odsyła w swej „małej” narracji choroby do narracji „wielkich”, obejmujących całe przyszłe dzieje globu, dokonujące się w teraźniejszych przesileniach, „podrzutach historii”. W takim, z grubsza tu nakreślonym, rozumieniu choroby, Krasiński jawi się jako wyznawca medycyny romantycznej. Jak pisała Płonka-Syroka: „W programie fizjologii romantycznej podstawowym organizmem jest wszechświat, ożywiona Całość (makrokosmos), której elementami są poszczególne poziomy struktury bytu"2o. W tym ujęciu, inspirowanym brownizmem, jednostka „odbiera” bodźce płynące z kosmosu, natomiast jak podkreślał to Lorenz Oken, naturalne siły, jak magnetyzm, elektryczność, eteryczność - którymi żywo interesował się Krasiński - będące przejawami działania ducha w naturze, mogą być odbierane przez jednostkę za pośrednictwem układu nerwowego $^{21}$. Koncepcję Okena rozbudował Carl Gustav Carus, zwracając uwage na rolę układu nerwowego dla prawidłowego odbioru bodźców przenikających z żywego i poddawanego nieustannym metamorfozom wszechświata. Zaburzenia funkcjonowania układu nerwowego byłyby tyleż skutkiem, co przyczyną choroby; przyczyną - jeśli siły duchowe tkwiące w naturze oddziaływałyby na jednostkę, powodując jej dysharmonię, skutkiem - o ile bowiem „zakłóceniu” ulega nadrzędny wobec człowieka porządek Całości, choruje też on sam, odbierając owe „zakłócone” bodźce ${ }^{22}$. Choroba jest w tym ujęciu zjawiskiem pozasomatycznym, zakorzenionym w rzeczywistości metafizycznej, jest bytem oderwanym od jednostki, odsyłającym do owego wyższego, ponadnaturalnego porządku ${ }^{23}$. Choruje planeta, i choruje człowiek - na zasadzie analogii, bezpośredniego wpływu makrokosmosu na jednostkę.

W jednym $z$ listów Krasińskiego możemy przeczytać pewne ogólniejsze sformułowania poety, odnoszące się do ówczesnych standardów medycz-

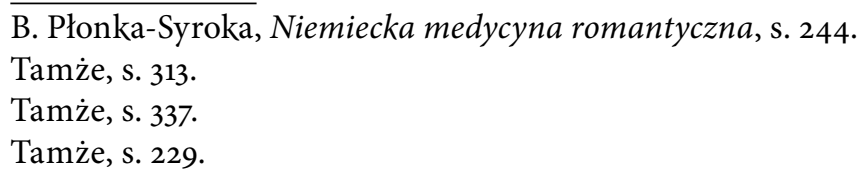


nych. Odrzucał on bowiem medycynę włoską i francuską, oparte na doświadczeniu i standardzie somatycznym, opowiadał się natomiast za niemiecką medycyną romantyczną, której reprezentantem miał być jego osobisty lekarz Chelius. W 1845 roku pisał do Delfiny Potockiej:

Ale d[okt]or niemiecki, oświecony i głęboki, niezbędny dla niej. Włosi to zwierzęta w medycynie, Francuzi zaś o duchu w sztuce lekarskiej nie wiedzą. Empirycy, Doświadczyńscy, materialiści, a wreszcie ignoranty, bo o Vichy tylko słyszeli, natur północnych naszych nie znają, leczą sposobami obrzydłymi naturom naszym, Niemcy zaś, osobliwie nadreńscy, wszystko znają i wiedzą. Na środkowym punkcie wszechnauki i wszechdoświadczenia stoją.

(LDP II 676)

A jednak, w owej specyficznej konstrukcji fabuł ciała i choroby, że odwołam się do świetnych analiz Bieńczyka, tu i tam przenikają ślady innego jeszcze dyskursu - powiązanego $z$ dokonującym się procesem odchodzenia od standardów niemieckiej medycyny romantycznej ku medycynie somatycznej (opisanym w książce Płonki-Syroki) - który można określić mianem dyskursu somatycznego. W przytoczonym liście Krasiński w istocie zwraca uwagę na eklektyczny charakter medycyny niemieckiej i tym samym potwierdza dokonujący się w niej ów proces przejścia ku zwycięstwu ujęcia somatycznego. Jest to wszakże ślad dokonującej się zmiany, która w latach pięćdziesiątych - mimo iż zasadnicze ramy dyskursywne pozostaną te same - będzie jednak powoli narastała i modyfikowała dotychczasowy dyskurs poety. Można to prześledzić na obszerniejszym materiale epistolograficznym.

\section{DWA CIAŁA POETY}

Na przełomie 1841 i 1842 roku w liście do Adama Sołtana pisał poeta - czy aby wyłącznie o swoim stanie zdrowia?

Cierpię niestworzone awantury tyczące się hemoroid, nogi mi się poraniły i popuchły, chodzić nie mogę, tymczasem ruch tylko mi zbawcą. Bez ruchu coraz lepiej grząznę, to śledziona, to serce, to wątroba się kłaniają. Oczy lepiej, ale cała waga złego przeniosła się do żołądka, i tam stacza tę bitwę, która po wielu marszach i przeciwchodach nareście zwycięży mój mikrokosm i rzuci go w pył ofiarniczy makrokosmowi! Duch wtedy sam się stanie makrokosmem, tj. obejmie, ogarnie, co Bóg i natura!

(LAS 416)

Kolejny raz ujawnia się przekonanie Krasińskiego o korespondencji między ciałem a kosmosem. Ale w tym liście, w jego dalszych partiach, pojawi się istotny kontekst myślowy dla przedstawianych tu rozważań o chorobie obejmującej cały organizm, a ogniskującej się w żołądku. Dlaczego tam? Bieńczyk pisał, że „[...] ośrodkiem rządzącym ciałem jest tu żołądek, miejsce 
właśnie przemiany, ruchu, a nie stabilności, ustalonego kształtu”24. Dla François Broussaisa, sławnego w epoce francuskiego medyka, prawie wszystkie stany zapalne i choroby (jak gruźlica, zapalenie płuc, syfilis) były „niczym innym jak stanami zapalnymi na tle żołądkowo-jelitowym, które należy leczyć ograniczaniem pokarmów (metoda osłabiająca) oraz naturalnie przystawianiem pijawek", jak komentuje współczesny historyk ${ }^{25}$. Dla Krasińskiego wszakże, ta „bitwa” toczona w żołądku ${ }^{26}$ - powtórzmy za poetą „zwycięży mój mikrokosm i rzuci go w pył ofiarniczy makrokosmowi” - jest zapowiedzią innych zgoła wydarzeń. Co znaczy, że - jak czytamy w dalszej części listu - w kosmosie coraz bardziej uobecniają się zapowiedzi zbliżającej się „trzeciej sfery”: Czynu. I ciało - przynależące do epoki drugiej, epoki Woli, musi przeistoczyć się w inne zgoła ciało: odczuwające ów kosmiczny charakter dokonującej się zmiany, a droga do tego wiedzie przez chorobę. I w myśli Krasińskiego uobecnia się owo inne jeszcze ciało, a właściwie zapowiedź ciała „trzeciej epoki”: jego kształty kreśli w listach do Delfiny Potockiej, jego wyobrażenie przedstawi w Przedświcie.

Można byłoby powiedzieć, że w ramach dyskursu o ciele i chorobie Krasiński wyróżnia dwa ciała: jedno, to jest to ciało cierpiące, składające się z wątroby, serca, żołądka, nerwów i mózgu. I drugie ciało - w tym materialnym zawarte, jakkolwiek połączone tajemną więzią z makrokosmosem, będące zapowiedzią ciał przemienionych „trzeciej epoki”: eterycznych, poruszanych drganiem kosmosu. To drugie ciało, będące w pierwszym - postawmy istotne pytanie, czy ono choruje?

Epistolografia Krasińskiego dostarcza wielu dowodów na duchowo-cielesne postrzeganie ja, lecz równie niezliczone symptomy choroby dotyczą jednakowoż ciała "pierwszego”. I choć wiele pisze o melancholii jako doświadczeniu sprzężonym z kryzysami ciała - zauważają ów związek także inni adresaci jego listów, wśród nich zwłaszcza żona poety w swej korespondencji - to kuracji poddawane jest ciało „pierwsze”. To dość charakterystyczne, że na poziomie notacji epistolarnych Krasińskiego bolą oczy, nogi, żołądek, „muszkuły”. Czy boli ciało „drugie”? Jednak boli. Boli „nerwami”, które

24 M. Bieńczyk, dz. cyt., s. 76.

25 G. Cosmacini, Lekarz, w: Człowiek romantyzmu, pod red. F. Fureta, przeł. J. Łukaszewicz i J. Ugniewska, Warszawa 2001, s. 202.

26 Warto przytoczyć świadectwo pozostawione przez żonę poety, która w jednym $\mathrm{z}$ listów z 1858 roku pisała o chorobie Krasińskiego: „Teraz żołądek jest siedzibą tej choroby, która u niego raz rzuca się na oczy, to znów na mózg, na pierś lub kręgosłup, a która zwyciężona w jednym miejscu wybiera sobie inne pole bitwy" (LEK III 254). I Krasiński, i jego żona, pisząc o chorobie, operują podobną militarną metaforyką - choroba to bitwa, przeciwnika można więc pokonać albo on zwycięży pacjenta. 
odczuwają zaburzony rytm kosmosu i zarazem są „zapowiedzią” dokonującej się w ciele zmiany. Boli też mózgiem, wątrobą, śledzioną - bo to w tych narządach dokonuje się pewien niejasny i niejawny proces przekształcania ciała w owo ciało inne, zapowiadające ciała przemienione „trzeciej epoki”:

Dopiero cudami, gdy w ciele coś nadzwyczajnego się przetwarza, ale do takich przetworzeń trzeba przygotowania, trzeba rozdrażenienia najwyższego. Dochodzim, dochodzim wszyscy do takowego, i wkrótce cuda się zaczną u nas pokazywać. Ciała nasze drgać będą [...]. Czy nie czujesz, że ku temu się nerwy mają?

(LDP III 418)

W tym wywodzie Krasiński podkreśli, że „oczywiście cuda się na ciałach, nie duszach okazują” (LDP III 418). Ciała - cierpiące, „rozdrażnione” nerwowo, chorujące - są więc jakby niezbędne dla kosmicznej zaiste przemiany czyli ozdrowienia, polegającego na przeistoczeniu w ciało „wyaniołowane”, jakie na swoich płótnach przedstawiał Ary Scheffer, odnajdujący z kolei w swoim ciele - jak czytamy w jednym z listów - ów tajemny „elektryczny fluid” (LRA I 556) przenikający kosmos, przynoszący zapowiedź innego ciała:

Boskie piękno staje się w nas ciałem i krwią lub raczej światłem, elektrycznością, kolorem, dźwiękiem, muzyką, drganiem - potem wieczna miłość pociąga nas coraz wyżej, coraz bardziej naprzód.

(LRA I 559)

Tak pisał poeta w połowie lat czterdziestych XIX wieku. I jakkolwiek sam - konsekwentnie - ujmuje swoją chorobę w innych kategoriach, bliższych pojęciom medycyny romantycznej, to gdyby wnioskować z listów z ostatnich lat życia Krasińskiego, napisanych przez poetę (i jego żonę), uderzającą cechą dyskursywizacji choroby będzie coraz wyraźniejsze lokowanie jej w kategoriach somatycznych: osłabiania poszczególnych narządów i całego organizmu. Czy jednak byłoby to równoznaczne z przechodzenia pacjenta (i jego lekarza) na pozycje bliższe ujęciom somatycznym? Trzeba zachować tu dużą ostrożność. Dokonujący się powoli proces „modernizacji medycyny”, którego istotą

[...] było stopniowe przyjmowanie przez myśl medyczną poszczególnych krajów europejskich ukierunkowania somatycznego i anatomicznego, a także opartego na podstawach empirycznych modelu poznania. Modernizację medycyny pojmowano także jako proces stopniowej eliminacji przesłanek metafizycznych z wewnętrznej struktury pojęciowej medycyny, prowadzący do „odczarowania choroby” i nadania jej wymiaru naturalistycznego. ${ }^{27}$

- może być pewną ramą kontekstualną dla pojawiających się - warto to podkreślić - jednakowoż odmiennych od wcześniejszych wyobrażeń o ciele i chorobie.

27 B. Płonka-Syroka, Niemiecka medycyna romantyczna, s. 168. 
Postępujące wyniszczenie organizmu sprawiało, że chociaż Krasiński stale pisze o równoległej, by tak rzec, chorobie ciała i duszy, to reakcje somatyczne nie pozostawiają złudzeń ${ }^{28}$. Cierpi ciało, zaś cierpienie nie zawsze będzie miało wzniosły charakter. I chociaż będzie pisał o większym cierpieniu wynikającym z melancholii, to cierpienia „cieleśne”, jak je określał, nie pozostawiają złudzeń:

[...] dostałem napadu straszliwego na pęcherz, przez 4 godziny tarzałem się, w niebogłosy rycząc, po podłodze.

(LAC I 660)

Od dni 15-tu mam grypę, która nie chce się skończyć i męczy mię niesłychanie, rozum odejmuje, pozbawia zmysłów prawie wszystkich i płuca psuje znakomicie. Cierpię mocno.

(LAC I 713)

Mój drogi! To był wrzód w gruczole pod pachą. Pękł i minęło. Lecz teraz co innego - kaleką się stałem i od kilku dni chodzę na kuli pod lewą pachą, a na kiju w lewej ręce. Napadu podagry w kolano dostałem. [...] Cierpię ogromnie cieleśno - nie mogę bez ryku wstać ni usiąść, ni przewrócić się w łóżku - ale to lepsze od melancholii.

(LAC I 724-725)

To pewna część znacznie obszerniejszej całości. Jak można się zorientować, dokonuje się tu pewna zmiana i w myśleniu, i w pisaniu o chorobie. Choroba jest odzierana ze wzniosłości, uzyskuje charakter fizjologiczny - Krasiński nie szczędzi swym adresatom, zwłaszcza Jerzemu Lubomirskiemu i Augustowi Cieszkowskiemu szczegółów właśnie fizjologicznych, często przy tym utrzymanych w nowej poetyce diagnozy lekarskiej. Coś tu się zmienia - jeśli porównamy niżej przytoczone fragmenty z wcześniej cytowanym listem do Delfiny Potockiej, w którym poeta przybierał pozę romantycznego lekarza: ciała i duszy. Tu jest inaczej. Ciało cierpiące nie odsyła bowiem do koncepcji ciała przemienionego, nie mówi się o duszy, lecz o płynach, upławach, stawach, zapaleniach:

Mój drogi! Dzięki Ci za receptę na podagrę, ale niestety już nie z podagrą mam do roboty, jedno z czymkolwiek gorszym daleko. W skutku bowiem pierwiastkowego napadu podagrycznego wyrobiło się zapalenie w samym stawie (articulation) kolana i nastąpiło znaczne bardzo wycedzenie się (exsudation de synovie) tego płynu niejasnego, który napełnia stawy kolanowe. Stan takowy zwan jest: zapaleniem reumatycznym ostrym (Inflammation rhumatismale aiguë) i leżą w nim dwa niebezpieczeństwa, gdyby nieostrożnie się do niego człowiek miał lub niedobrze się nań leczył: 1-mo można na zawsze postradać władzę w kolanie, 2-do takie zapalenia stawów kolanowych

Można pokusić się o stwierdzenie, że w romantycznym doświadczaniu choroby funkcjonują owe dwa porządki: dolegliwości fizycznych, jak chociażby bóle zębów, przewijające się stale w korespondencji filomatów i cierpień duszy, mających swój wykładnik organiczny - jak „bajroniczny ból głowy”. Zob. L. Libera, Choroby wileńsko-kowieńskie, w: tegoż Mickiewicz i medycyna..., s. 89. 
szczególny mają związek z sercem i lubią czasem nagle przenosić się do serca, a wtedy źle. Walther, tu z Drezna przybyły [...] odkrył to wszystko, nakazał mi jak najspokojniejsze leżenie i merkuriuszową maścią oblepił mi kolano.

(LAC I 731)

Opisywałem Ci pozawczoraj stan mego zdrowia - od 1² miesiąca znów ukazujące się w ogromnej obfitości upławy, i zapowiadałem $\mathrm{Ci}$, że w tych dniach operacją mi Chelius zrobi. Chelius zdumiony, że wreście o le j t e n na wierzch wyszedł i że choć Lallemand zaprzeczył, jednak tak jest. Lecz teraz powiada, że rozumie wreście stan mój cały i wszystkie jego niepojęte anomalie, zwane niegdyś b r a k i e m w o l i we mnie.

(LJL 606)

Być może nie należy przeceniać słowa „niegdyś”, które poeta włożył w usta Cheliusa. Ale, kto wie, może byłby to ważny trop wskazujący na dokonującą się zmianę standardów medycyny w postrzeganiu choroby. Doktor „niegdyś” ten stan nazwałby „brakiem woli”, wskazując tym samym na psychosomatyczne rozumienie choroby. Obecnie - obserwując „olej ten”, który wydobywa się z ciała Krasińskiego, będzie może bardziej leczyć ciało niż chorującą duszę romantycznego poety.

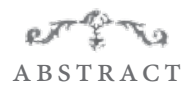

\section{Zygmunt Krasiński TAKING The WATERS}

The article presents Zygmunt Krasiński’s experiences and feelings connected with his illness in the context of the medical civilisation of his time. His stays in numerous health resorts and the water therapies which he receives there (hydrotherapy and balneotherapy) are regarded as manifestations of a broader phenomenon, namely a transition from German Romantic medicine to the standards of somatic medicine which emerged in the middle of the nineteenth century. Discursive evidence of his illness, obtained from the poet's epistolary sources and from his wife's letters, was analysed in this aspect. On the one hand, due to parallel treatment of the body and the cosmos (an illness as a disharmony of the two orders), the ailing body and a troubled soul were understood to be a prerequisite for a spiritual metamorphosis of man and the world. On the order hand, there emerged an attempt to approach an illness from a somatic perspective, which was concurrent with the change of the medical standards of that time - an illness was no longer a domain of the romantic sublime, it became a physiological experience. In spite of the trend, however, Krasiński remained a supporter of perceiving his illness in a romantic way, with spiritual sphere regarded as superior to somatic sensations.

\section{KEYWORDS}

Zygmunt Krasiński, body, soul, illness, German Romantic medicine, somatic medicine 